\title{
名古屋大学におけるWebCTの日本語化と 大学教育用情報基盤の今後
}

\section{梶田将司 ${ }^{1}$}

著者抄録 : 本稿では, 北米の高等教育機関におけるe-Learningプラットフォームとして最も普及して いるWebCTの現状について述べるとともに, 1998年から名古屋大学情報メディア教育センターで行 われているWebCTの日本語化活動の現状および利用事例についても述べる。また, WebCTの活動を 通じて見えてくるトレンドとして (1) 学務情報システムとの連携 (2) キャンパスポータルとの連 携を紹介する。近い将来, 日本の大学教育においても (1) WebCTのようなコース管理システム (2) 学務情報システム (3) それらのエントリーポイントとなるキャンパスポータルは, 必要不可欠なも のになると考えられる。これらを活用したインターネット時代の大学教育用情報基盤が整備される ためにも, まずは, その核となるWebCTのようなコース管理システムの普及が望まれる。

キーワード : 高等教育, WBT, WebCT, コース管理システム, キャンパスポータル

\section{Localization of WebCT in Nagoya University and a perspective of higher educational information basis}

\begin{abstract}
KAJITA Shoji ${ }^{1}$
Author Abstract: WebCT that has been used widely in higher educational institutes of North America is going to be a mission critical e-Learning platform in on-campus education, rather than mere WBT system. In this paper, we describe WebCT localized by Nagoya University and its current status at first. Secondly, we introduce two critical trends for educational information basis that we can observe in the movement of WebCT, (1) the cooperation with existing student information system, and (2) campus portal that provides university-wide one-stop service for all member of the institution. We have already had all of technologies in our hands that would be necessary for higher educational institutions in the first decade of 21 century. To move the direction, course management system like WebCT should be widely used in Japan.
\end{abstract}

Key words: higher education, WBT, WebCT, course management system, campus portal

\section{1. 概要}

急速に進んでいる知識集約社会における生涯教 育の充実や, 国立大学の独立行政法人化, 少子化 に伴う大学全入時代の到来など, 大学教育を取り 巻く状況は大きく変化しつつある。このような流 れの中で, インターネットを利用した大学・大学 院講座の開講や, バーチャルユニバーシティ構築

1名古屋大学情報メディア教育センター（†464-8603 愛知 県名古屋市千種区不老町1）Tel. 052(789)3626

E-mail:kajita@media.nagoya-u.ac.jp

${ }^{1}$ Center for Information Media Studies, Nagoya University

(Furo-cho 1, Chikusa-ku, Nagoya-shi, Aichi, 464-8603)
の議論に見られるように, 情報通信技術を活用し た大学教育の質的転換の可能性が日本でも芽生え 始めているものの, 講義を中心とした通常の大学 教育に波及するまでには至っていない。

一方, 情報通信技術の大学教育への導入が日本 よりも進んでいる北米の高等教育機関において,大 学教育現場への普及が著しいWebべースの教育支 援システムとしてWebCT (Course Tool) やBlackboard がある。そのうち, 北米で最も多く利用されてい るものが, カナダのブリティッシュコロンビア大 学で開発されたWebCTである。2002年1月現在, WebCTは80か国の2,527の高等教育機関で使用され ている1)。このようにWebCTの利用が急速に広がっ 
ている理由は,対面講義を前提としているオンキャ ンパスの講義において, 補完的な教材・学習環境 の提供を目的として利用されるケースが急速に増 えているためである。このように，高等教育機関 での講義（コース）を中心とした教育活動に必要 不可欠な「コース管理システム」としてWebCTは 発展しつつある。

そこで, 本稿では, 北米の高等教育機関におけ るe-Learning プラットフォームとして最も普及して いるWebCTの現状について述べるとともに，1998 年から名古屋大学情報メディア教育センターにて 行われているWebCTの日本語化活動の現状および 利用事例についても述べる。また, WebCTの活動 を通じて見えてくるトレンドとして (1) 学務情報 システムとの連携 (2) キャンパスポータルとの連 携を紹介する。近い将来, 日本の大学教育におい ても, (1) WebCTのようなコース管理システム 学務情報システム (3) それらのエントリーポイン 卜となるキャンパスポータルは, 必要不可欠なも のになると考えられる。これらを活用したインター ネット時代の大学教育用情報基盤が整備されるた めにも,まずは,その核となるWebCTのようなコー ス管理システムの普及が望まれる。

\section{WebCT}

WebCTは, カナダのブリティッシュコロンビア 大学 (University of British Columbia UBC) で開発さ れたWebを用いたコースの設計, 開発, 管理を容 易にする統合コース管理ソフトウエアである。同 大学講師のMurray W. Goldbergは, Webベースのコー スを1995年から作り始め,その中から生まれたツー ル群の研究発表をWWW5で行ったことがきっかけ となり, 世界中に広がり始めた ${ }^{22}$ 。当初は, 独自の 研究資金を使って開発・保守を行い, 無料で配布 していたが, 世界中の約100の機関で利用されるま でに広がってしまったため, WebCT Educational Co. を起業し，現在に至っている33。

WebCTを用いれば，技術的なことに精通してい ない教官でもWebべースのコースを簡単に作成す ることができる。また，すでに作成されている教 材（例えば, PDF化・PowerPoint化された講義資料 など）をWebCTを通じて学生に閲覧させることも できる。さらには, コース内で使用するさまざま なツールも用意されている。例えば, 電子掲示板, メール, オンラインチャット, 成績の保守および 通知機能, アクセス制限機能, 自動採点が可能な
クイズ出題機能, コースカレンダー, 学生用ホー ムページ, コース内容の検索, ホワイトボード, シ ラバスツール, 宿題提出・回収ツール, Webコース ビルダーなど, 非常に豊富なツールがあらかじめ 組み込まれており，使用するかどうかは選択が可 能である（図1）。また，コース全体を把握しやす くするため, コースナビゲーターやコースマップ など工夫が凝らされている。

\section{1. 主な機能}

WebCTでは,

(1) コースの概観を設計することができるインタ フェース (色調の設定, ページレイアウトなど)

(2) 学習や, コミュニケーション, 協調学習を容易 にするための教育用ツール群

(3) コースの管理作業や改良作業においてデザイ ナーを手助けする管理ツール群

により, Webべースのコースを容易に構築できる。 これらを通じて提供される機能の一部を紹介する。

○コンンツモジュールによる講義ノートの作成 講義ノートに対応するコースコンテンツページ は，WebCTコンテンツモジュールを使用して作成 する（図2）。コンテンツモジュールツールは，学 習目標に至る「道 (パス)」にさまざまなノートや オンラインクイズ, リファレンスなどを効果的に 配置し, 学習者を学習目標に導くため,「パス」ツー ルと呼ばれる場合もある。各ページは一般的なWeb ページオーサリングソフトウエア (Netscape Composerやマイクロソフト社FrontPageなど) や HTMLで保存可能なワードプロセッサソフトウエ ア（ジャストシステム一太郎，マイクロソフト社 Wordなど）を使用して作成し, WebCTファイルマ ネージャを使用してWebCTサーバにアップロード したものを順次登録する。ノート中に出現する用 語については, WebCT用語集にあらかじめ登録し ておけば，用語集へのリンクを自動的に作成する ことも可能である。

学生管理データベース

WebCTに登録された学生に関する情報は, 学生 管理データベースを通じてコース内のさまざまな 情報（例えば, オンライン試験の結果や, 学習の 進捗状況確認など）とリンクされる（図3）。クイ ズッールや宿題ツールを使用して採点された結果 は, すべて学生データベースに反映されるため, デザイナーは学生データベースを通じてすべての 成績を一元管理可能。学生データベースの内容は CSV形式でデータをダウンロードし，ローカルコ 
紹介 の名古屋大学におけるWebCTの日本語化と大学教育用情報基盤の今後

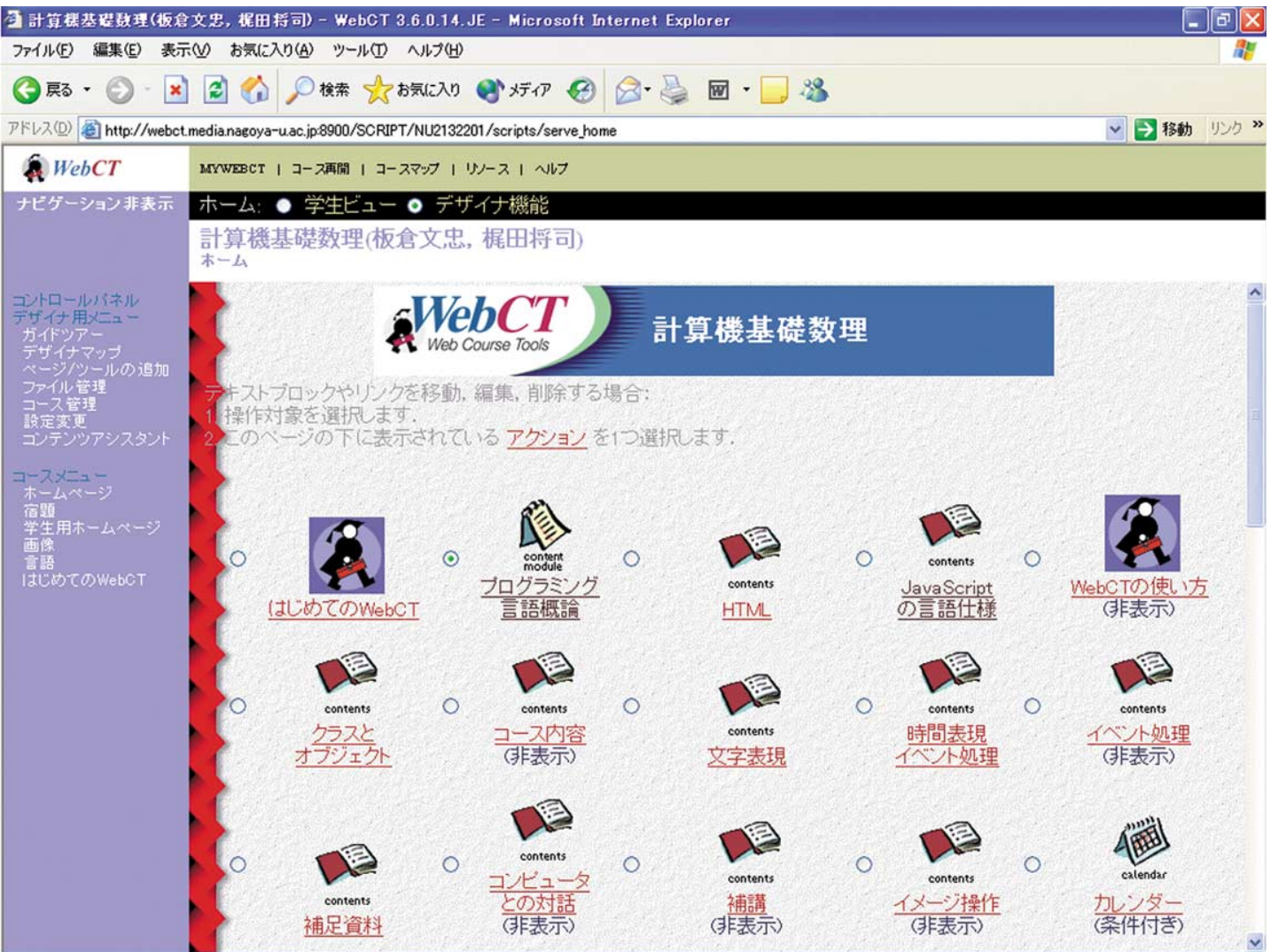

図1 WebCTによるコース構築例（デザイナー画面）

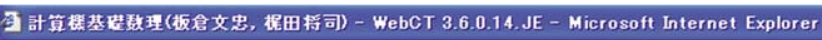

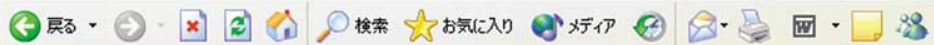

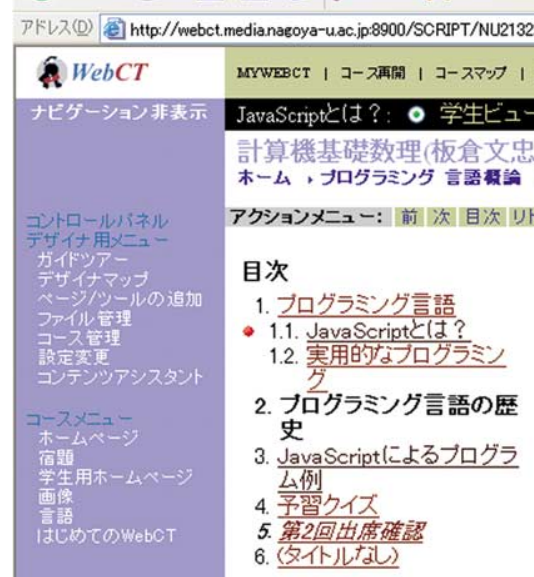

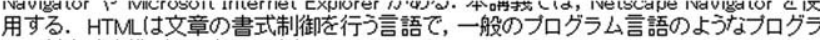
ムの流れを制御することはできない。

HTML大好理の流れを制御するための言語としては，今回取り上げる JavaScript や Javaがある. JavaScript は Java ほど複雑なコントロールはできないが,

・ブラウザさえあれは動作する,

- HTML内に直接記述するため分かり易い,

・ Javaほど言語仕様が難しくない,

といったように, プログラム経験のない人で理解易い言語である. JavaScript を使え ば,Webベージを動的に变化させたり, 今までCGIなどで行う必要があった処理の一部を。 Webベージ上で行うこことが可能こなる。

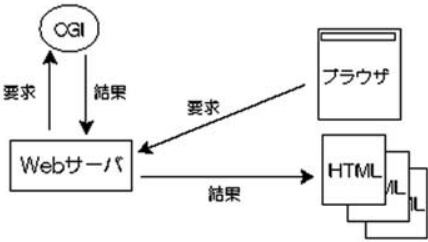


管理 Vol. 45 No. 1 April 2002

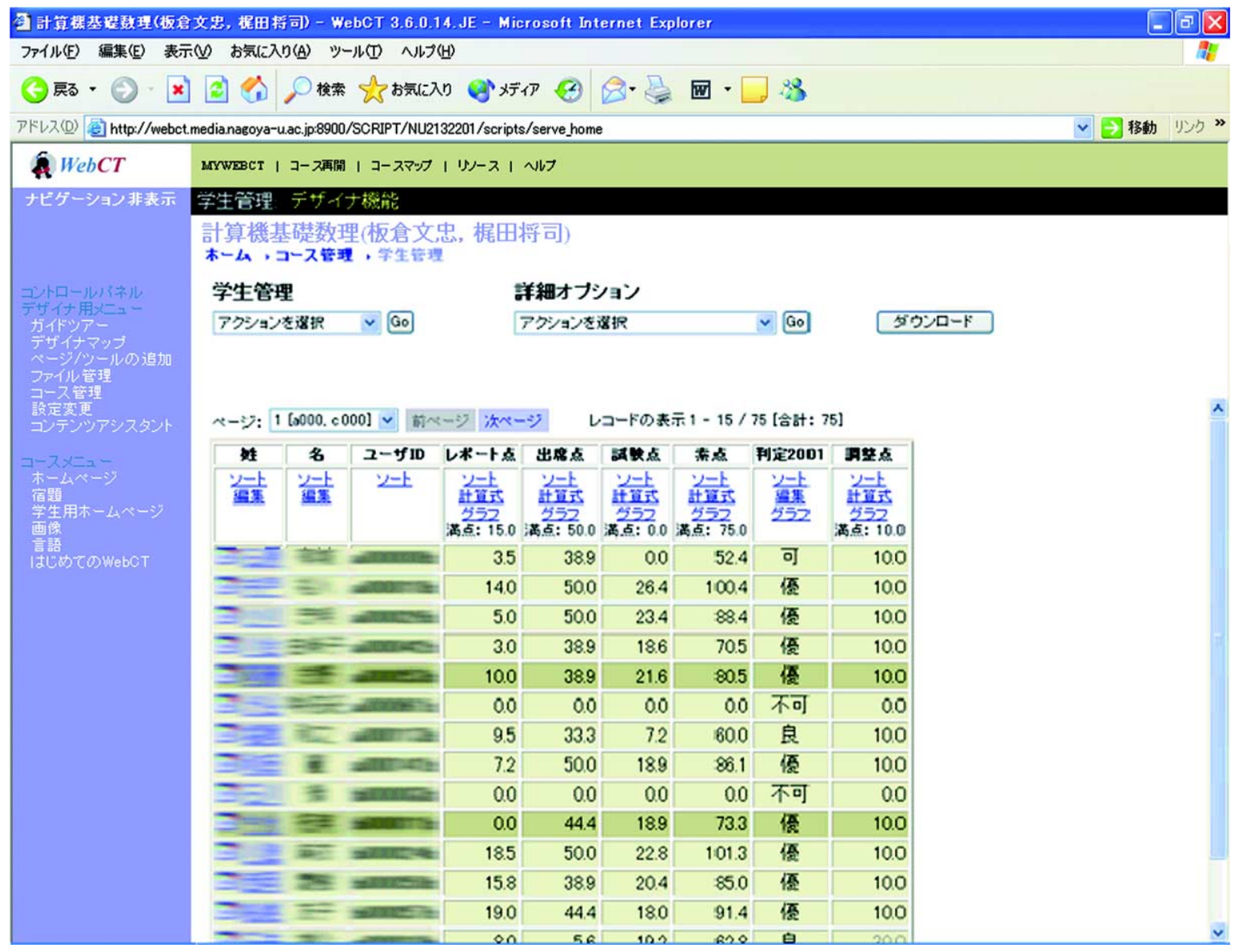

図3学生管理データベース

ンピュータにてExcelなどの表計算ソフトウエアに より編集し,再度アップロードすることで学生デー タベースの内容を更新することも可能である。

○学習状態に応じた教材提示

WebCTのホームページに表示される各種ツール のアイコンを学生に提示する際の条件として 特定の学生のみ公開 (2) 学生管理データベースの 状態に応じて公開 (3) 日時を指定して公開の3つ がある。例えば, (2)の場合, あるオンライン試験 で60点以上採らないと公開されない教材やッール を作成することができる。

○電子掲示板・電子メール

Webブラウザから利用できる専用の掲示板・メー ルがコースごとに用意され, 教官一学生, もしく は学生どうしのコミュニケーションをコース内で 行うことができる。

○ チャット

Javaアプレットによるチャット。会話内容の保 存も可能。

自動採点が可能なクイズ出題
日時・時間・制限時間を設定可能なオンライン クイズ（試験）の出題ができる仕組みが用意され ている。選択問題などのクイズについては, あら かじめ正解を設定しておくことで自動採点が可能 である。

課題レポートの出題・回収機能

宿題ツールを使用することにより, 課題しポー トを学生に課し,それをファイルとしてアップロー ドさせることができる。レポート提出時の受領確 認や教官・TAへの通知機能, 採点機能もある。

○成績の保守および通知 オンラインクイズの結果や, 講義の最終結果な どを学生にフィードバックできる。

・コースカレンダー

用意されているカレンダーには，デザイナーに よりコースに関する予定が掲示できるだけでなく， 学生自身の予定も書き込むことができるようになっ ている。

・アクセス制限 コースにアクセスできるのは, 基本的に登録さ 
れた学生だけであるが, ゲスト登録もできる。

\subsection{WebCTで用いられるアクセスモード}

WebCTサーバへのアクセスモードとして，

(1) 管理者モード

(2) デザイナーモード

(3) ティーチングアシスタントモード

(4) 学生モード

の4つが用意されている。管理者モードへのアクセ スはadminアカウントで行う。デザイナー・学生 ·

TA モードについては, 各ユーザはまず各自の myWebCTアカウントで自分のmyWebCTにログオン し,そこから各コースにアクセスすることで,コー スごとに定められている権限に従って自動的にモー ドが選択される（図4）。

(1) 管理者モード

WebCTサーバに関する基本的な設定を行うモー ド。このモードにより，管理者は各コースの作成， バックアップ, ディスクスペースなどのリソース 使用状況，コースカテゴリーの設定などが行える。 新規コース作成時には，すでに存在するコースを
ベースに作成できるため, 各サーバでのデフォル 卜設定を準備しておけば，デザイナーの負担を軽 減することができる。また, myWebCT (次節参照) のIDを管理するグローバルユーザデータベースに 対する検索や，管理者を補助するアシスタントの 登録, 全ユーザに対する連絡事項のmyWebCT画面 での通知, 全ユーザに共通するブックマークの提 供などが可能である。

(2) デザイナーモード

各コースのコンテンツの作成・変更, オンライ ンクイズの作成・採点・集計, 学生の学習状況の 追跡など, WebCTの中心となるモード。デザイナー モードでは, 学生モードでの画面と, それを作成 する各種操作用のボタンが配置される（図 1）。 WebCTのデザイナーマップを使用すると, デザイ ナーモードで使用可能なすべての機能に2回のク リックでアクセスできる（図5）。また, 複数の教 官で作業を行うための共有デザイナーアクセスモー ドも用意されている。

(3) ティーチングアシスタントモード

TAなどの講義補助者に, オンラインクイズの採

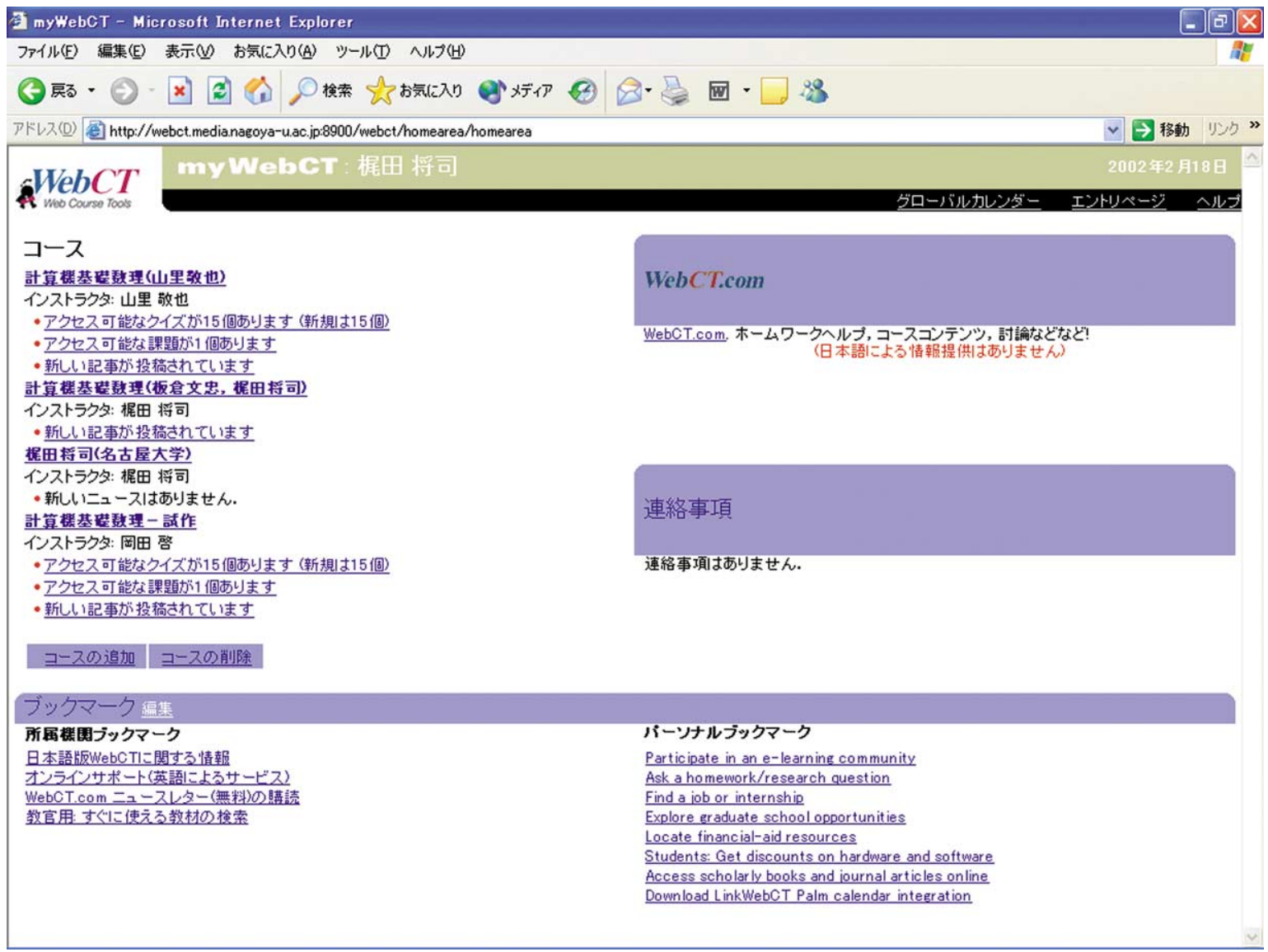




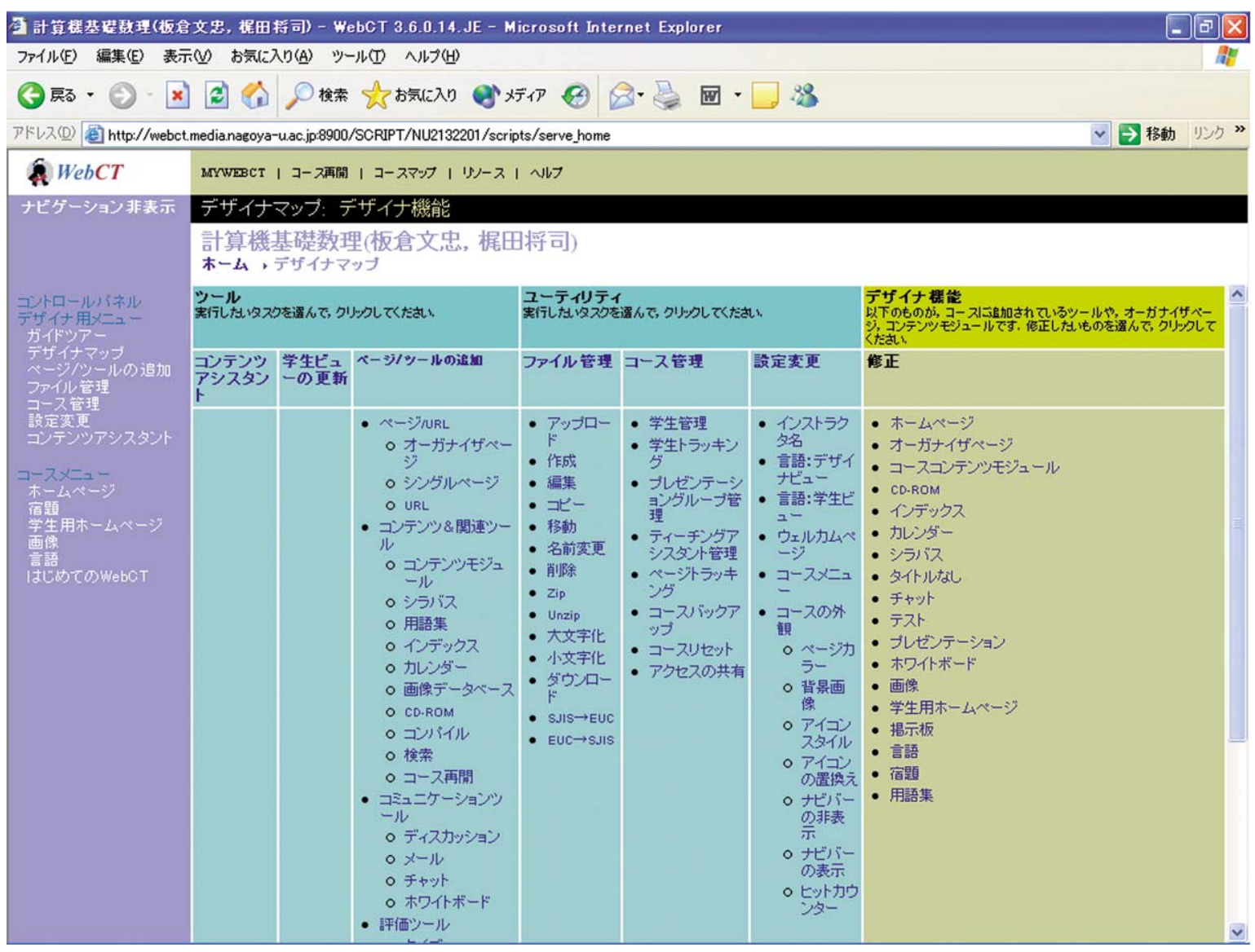

図5 デザイナーマップ

点やレポートの採点を行わせる場合に用いるモー ド。成績管理用の学生管理データベースにもアク セスできる。

\section{(4) 学生モード}

デザイナーにより作成されたコースコンテンツ を閲覧するモード。学生はすべてこのモードで WebCTサーバへのアクセスを行う。メール，掲示 板, チャットなど, すべてのWebCTッールもこの モードで利用できる。

\section{3. myWebCT}

デザイナー, ティーチングアシスタント, 学生 がWebCTにアクセスする際に使用するWebCTの工 ントリーポイントで, 各コースに関する情報 (メー ルや掲示板の記事, クイズ, 課題が新規にどれく らいあるかなど) や, 管理者からの連絡事項, ブッ クマークなどが表示される（図4）。各ユーザは myWebCT IDとパスワードを入力し, myWebCTに ログオンし, その後, 各コースにアクセスする。各 コースにアクセスする際はIDやパスワードを再度
八力する必要はない。

\subsection{WebCT普及の理由}

WebCTが急速に広がっている理由としては次の 7点が挙げられる。

(1) 高等教育機関における教育現場のニーズに常に 立脚し改善がなされている

(2) サポート体制が充実している

(3) ライセンス価格が安価であった（注：2002 年か らは無制限ユーザライセンスは年間 $\$ 10,000 /$ サーバ)

(4) WebCT のインストールおよびコンテンツの作成 だけであれば無料で利用できた（注：現在はラ イセンスキーを取得しないと利用できない)

(5) WebCT は http デーモンとして apache を使用して おり，CおよびPerlで記述されたCGIですべての 機能が提供されているため, 大学関係者にとっ て扱いやすい

(6) WebCT の利用者を中心にコミュニティが形成さ れている。これにより, e-Learningに関する議論 
をWebCTという共通のプラットフォームの上で 行える場が形成され,さまざまなノウハウが蓄 積されている

(7) e-Learning Hub Center <http://www.webct.com/>を 中心とした教材の共有化が行われており,すで に北米の約 50 社から約 1,000 の有料コンテンツ （e-Pack）が販売されている

\section{5. 名古屋大学における日本語化の取り組み}

WebCTは欧米で開発されたソフトウエアによく ある,2バイトコードに起因する問題が日本語環境 では生じる。名古屋大学情報メディア教育センター では，1998年にWebCT1.3の独占的日本語化権を取 得し, 非公開のソースコードを入手, WebCTのソ フトウエア的なローカライゼーションを行ってき た4)。また, 2000年11月からは最新版WebCT3.X日本 語版の開発も行ってきた。名古屋大学での日本語 化活動では, WebCTの1つのツールとして独自ツー ルを追加することができるアプリケーションプロ グラミングインタフェースも構築し, 日本の教育 現場で今後求められるさまざまな機能をWebCTと は独立に作成し，付加できるようになった。

\section{6. 教育用コンテンツ標準化への取り組み}

WebCTは, IMSやSCORMに関する教育用コンテ ンツの標準化動向に対して積極的に関与している。 例えば，WebCT3.5からはIMSに準拠した学生情報 システムとの連携が可能になった。また, 2001年7 月からは,IMS Content Packaging Specification 1.1に準 拠したコンテンツとしてWebCTで作成したコンテ ンツを書き出したり，IMS準拠のコンテンツを取 り込んだりすることが可能になった。

\section{WebCT利用例}

ここでは,名古屋大学情報メディア教育センター が全学向けに開講している計算機基礎数理での使 用方法を簡単に紹介する。この講義は, 文科系1, 2年生向けのコンピュータリテラシーの講義で, 同 センターの端末室にて行われる。毎回の講義は, コンテンツモジュールで作成した講義ノートを液 晶プロジェクタによりスクリーンに投影し，実施 した。学生は, スクリーンを見ながら講義を聞く ものもいれば, 自分の端末で同じコンテンッや付 随するリファレンス，用語などを参照しながら聞 く学生もいた。使用したWebCTツールは, 課題に 関するQ\&Aのためのディスカッションッール，レ
ポート課題の結果を教官・TAに分かりやすく提示 してもらうためのプレゼンテーションッール, 小 テストを実施するためのクイズツール, 講義アン ケートを実施するためのサーベイツールである。 WebCT利用の効果は正確には測定していないが, 講義アンケートの結果から, WebCTで提供される 非同期教育環境の特性を生かした講義の時間外活 用が確認できた（図6）。

\section{4. 大学教育用情報基盤の今後}

2章で紹介したように, WebCTは北米の高等教育 機関に急速に普及しつつある。その動きの中で, 高等教育機関における情報基盤として今後重要性 が高まってくると思われる学務情報システムやキャ ンパスポータルとの連携について紹介する。

\section{1. 学務情報システムとの連携}

WebCTは, 対面講義を前提としているオンキャ ンパスコースでの講義の補完的な教材・学習環境 の提供を目的として利用されるケースが急速に増 えている。その結果, 各大学がすでに所有してい る受講管理や成績管理を行う学務情報システムと の連携を急速に深めている。これにより，コース への学生登録作業や最終成績通知作業からコース を運営する教官を解放することができるので, 学 内においてWebCTのようなコース管理システムの 利用を広げるためには重要である。

\section{2. キャンパスポータルとの連携}

WebCTは，キャンパスポータルとの親和性を深 めることにより, 学生や教官がキャンパスポータ ルからWebCTで作成されたコースにシームレスに アクセスできるようになりつつある。

キャンパスポータルとは, 学生や教官, 職員, 卒 業生などのその大学の関係者や地域社会に対して, 教育活動や研究活動に必要なすべての情報・サー ビスの提供を行うWebサイト, つまり, 大学版り ンストップサービスを提供するWebサイトである。 各ユーザは, 自分のアカウントを使用してポータ ルにログオンすると, ユーザ共通の情報（システ ム主導型情報）が表示されるだけでなく, 各自が 複数のチャネルからあらかじめ選択した情報(ユー ザ選択型情報）が随時表示されるとともに, 大学 側からユーザに依存した情報 (ユーザ依存型情報) を提供することもできる。例えば, 学生がログオ ンすると, その学生が受講している講義に関する 


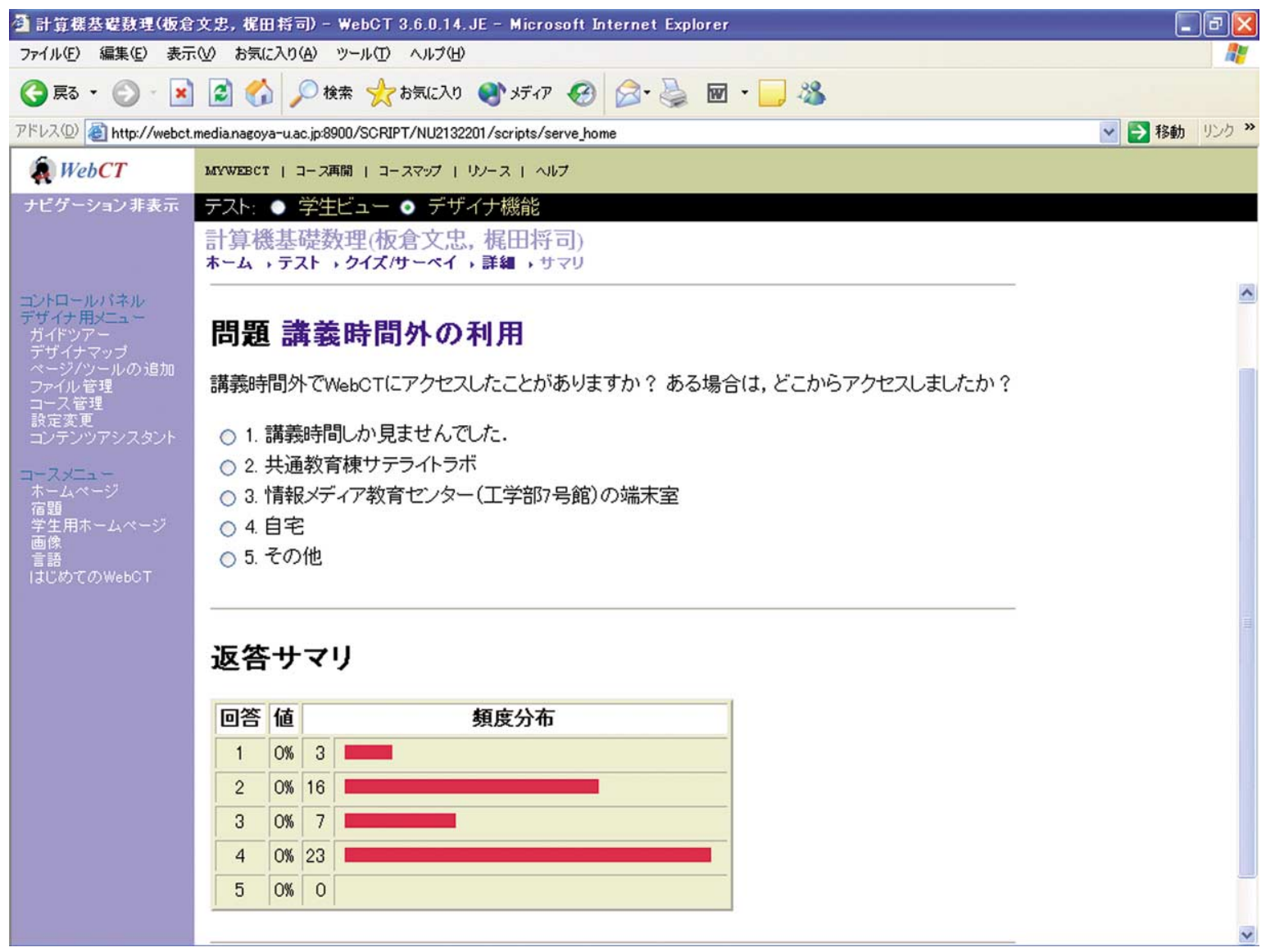

図6サーベイツールを使用した講義アンケートの結果

課題や休講情報が表示され, その学生が属してい るサークル情報やアルバイト情報・就職情報, 学 内ニュース, 時事ニュース, 天気予報, 交通情報 などを単一画面で見ることもできる。また, 大学 教務からの呼び出しや, 履修登録, 成績証明書発 行手続き, 学割申請などの各種手続きを行うこと もできる。講義情報については, コース管理シス テムと連携することにより, 予習復習だけでなく, レポートやオンライン試験実施などにシームレス にアクセスすることができ, 大学の教育活動を支 援するうえで決定的に重要である。このように, キャンパスポータルを導入することにより, 大学 内のさまざまな情報・サービスに対する統合的な ゲートウェイを大学構成員および地域社会に刘し て提供することができる。

最近, 一部の大学で導入され始めている休講通 知に代表される携帯電話やWebを利用した大学情 報案内は, キャンパスポータルのサブセットと考 えられる。しかし, WebCTのようなオンキャンパ スでの通常の講義を支援するコース管理システム
との連携を行っているものはない。また,インター ネットを通じた大学教育を実践しようという, い わゆる「バーチャルユニバーシティ」構築に関す る試みが行われているが, これらはあくまでもイ ンターネットを使った遠隔教育に関するものであ り, オンキャンパスでの通常の講義を支援するた めのシステム構築および運用に関する視点は十分 ではない。

北米では, the Java in Administration Special Interest Group (JA-SIG) によるフリーのポータルソフトウ エアuPortalの開発も行われている。uPortalは, 高等 教育機関用のポータルを作成するためのフレーム ワークで, JavaクラスのセットおよびXML/XSLド キュメントで構成される。uPortalは, JA-SIG, Java in Administration Special Interest Groupが, そのメン バーである教育機関が協力して開発を行っており, 無償でリファレンスインプリメンテーションとし てuPortalコードが利用可能になっている。

uPortalフレームワークを使用するために必要な Javaの知識のレベルには, 次の3つがある。 
(1)「管理レベル」と呼ばれるもので, 大学の要求 やITインフラストラクチャに応じてカスタマイ ズされたポータルを保守するためのレベルであ る。多くの部分は, DBMSやHTTPサーバを管理 することによく似ている

(2)「インプリメンテーションレベル」で, 各大学 の要求やITインフラストラクチャに応じてカス タマイズされたポータルを開発するためのレベ ルである

(3)「コンテンツ開発レベル」では, 実際にコンテ ンツやサービスを配信するために,「チャネル」 と呼ばれる番組（プログラム）を開発するため のレベルである

これら3つのレベルは, 明確に分けることはでき ず, 実際はかなりオーバーラップしている。uPortal は, Java 2が利用可能なすべてのプラットフォーム で実行可能である。JA-SIGのメンバーは, Microsoft Windows, Solaris, Linux, MacOS Xで開発を行って いる。

WebCTは, uPortalとの連携も可能である。

\section{5. まとめ}

本稿では, WebCTの現状について述べるととも に，その動きを通じて見えてくる教育用情報基盤 のトレンドとして, 学生情報システムとの連携, キャンパスポータルとの連携を紹介した。

WebCTの最大の特徵は, 北米の高等教育機関の 教官を中心に形成されているユーザコミュニティ の存在である。正確な規模を測ることは難しいが, 1999年から開催されているWebCTユーザカンファ レンスがその傍証となるであろう（1999年が約600 名, 2000年が約900名, 2001年が約1,000名）。この コミュニティを通じてさまざまなノウハウが蓄積 され進化した結果が現在のWebCTである。日本に おいても同様なコミュニティを形成し, 日本独自 のノウハウを蓄積するとともに，北米のコミュニ ティとの交流を通じて, 5〜6年先を進んでいる北 米に追いつくだけでなく, 教材やe-Learningツール を世界に向けて発信していくことが求められる。

\section{参考文献}

1) WebCT Inc. WebCT Company Homepage. (online), available from $<$ http://www.webct.com/company/>, (accessed 2002-02-19).

2) Goldberg, M. W.; Salari, S.; Swoboda, P. World Wide Web-Course Tool: an Environment for Building WWW-Based Courses. Fifth International World Wide Web Conference (WWW5), Paris, France, 1996.

3) Murray, W. G. "WebCT and trends in educational technologies”. 名古屋大学情報メディア教育セン ター主催「北米における e-Learningプラットホーム の現状」講演会. (オンライン) , 入手先 $<\mathrm{http}: / /$ webct.media.nagoya-u.ac.jp/>，参照 2002-02-19）.

4) Kajita, S.; Itakura, F. Development of Japanese version of WebCT and its use in Japanese online course. WebCT Asia Pacific Conference, Adelaide, Australia, 2000 . 